\title{
Hydrograph Debit Banjir Rencana pada Daerah Aliran Sungai (DAS) Tallo Makassar dengan Model Hidrologi HEC-HMS
}

\author{
Kezia $^{1}$, Mahmud Achmad ${ }^{1}$ dan Faridah ${ }^{1}$ \\ Program Studi Teknik Pertanian, Universitas Hasanuddin Makassar
}

\begin{abstract}
ABSTRAK
Bencana banjir merupakan salah satu persoalan utama masyarakat yang bermukim di daerah perkotaan dan area sekitar sungai. Daerah Aliran Sungai (DAS) Tallo adalah DAS yang secara administratif terletak ditengah kota besar, Makassar. Potensi kejadian banjir di DAS ini cukup besar karena posisi dan letaknya yang lebih rendah dari tinggi muka air laut dan alih fungsi lahan yang terus meningkat. Salah satu cara memperhitungkan bencana banjir adalah dengan menggunakan model Hydrologic Engineering Center's - Hydrologic Modeling System (HEC-HMS). Tujuan dari penelitian ini adalah untuk mengetahui besarnya debit banjir rencana yang akan terjadi selama periode waktu 2, 5, 20 dan 50 tahunan di DAS Tallo sehingga penentukan daerah-daerah yang rawan banjir dan kemampuan sungai dalam menampung banjir dapat diperhitungkan. Pengolahan data meliputi: 1. proses karakterisasi DAS Tallo menggunakan Global Mapper dan ArcMap, 2. menentukan nilai curah hujan rencana, 3. melakukan running data input dan parameter di HEC-HMS dengan metode SCS$\mathrm{CN}$, 4.mensimulasikan hasil permodelan pada ArcScene, dan 5. pengecekan/ground truth hasil permodelan pada titik-titik rawan banjir. Nilai debit banjir rencana yang diperoleh untuk periode ulang 2, 5, 20 dan 50 tahun secara berturut-turut adalah $81,80 \mathrm{~m}^{3} / \mathrm{s}, 115,30 \mathrm{~m}^{3} / \mathrm{s}$, $151,20 \mathrm{~m}^{3} / \mathrm{s}$ dan $169,50 \mathrm{~m}^{3} / \mathrm{s}$. Hasil tersebut disimulasikan di dalam ArcScene sehingga didapatkan lebar limpasan 2-8 m untuk periode ulang 5 tahunan, 2-25 m untuk periode ulang 20 tahunan dan lebih dari 25 m untuk periode ulang 50 tahunan. Sementara itu untuk periode ulang 2 tahunan tidak terjadi genangan sama sekali. Setelah dilakukan pengecekan atau groundtruth data di beberapa titik wilayah genangan, maka hasil simulasi di ArcScene sesuai dengan hasil ground truth tersebut. Dengan demikian, nilai debit banjir untuk setiap periode waktu pada DAS Tallo dapat dimodelkan dengan baik di HEC-HMS. Adapun, daerah-daerah yang secara administratif memiliki potensi terjadinya banjir akibat luapan sungai adalah daerah-daerah di sekitar pengaliran sungai terutama di daerah hilir.
\end{abstract}

\section{Kata kunci : Debit Banjir, Permodelan HEC-HMS, Hydrograph, Simulasi, Groundtruth.}

\section{PENDAHULUAN}

\section{Latar Belakang}

Bencana banjir merupakan
persoalan yang terus menghantui masyarakat khususnya untuk mereka yang bermukim di daerah perkotaan dan area sekitar sungai. Di Makassar terdapat beberapa sungai atau anak sungai yang semuanya mengalir ke Selat Makassar, salah satunya yaitu Sungai Tallo.Sungai Tallo mengalir melalui daerah Nipah, Kantisan, Bontosungi, Kera-kera, Lakkang, dan disekitar jalan tol.Disekitar Sungai Tallo tersebut terdapat beberapa pemukiman, industri, PLTU, industri pabrik tripleks, pertambakan dan pertanian, sekaligus sebagai tempat mata pencaharian bagi nelayan sekitar bantaran sungai.Letak sungai Tallo yang lebih rendah dari tinggi muka air laut dan alih fungsi lahan sepanjang daerah aliran sungai yang terus meningkat membuat potensi genangan banjir akibat luapan air sungai semakin tinggi.

Potensi banjir di suatu DAS dapat diperhitungkan melalui analisis hidrologi yang merupakan analisis penting untuk mengetahui besarnya debit rancangan. Dengan demikian, kerusakan akibat bencana banjir pada berbagai segi dan lini kehidupan khususnya bagi usaha pertanian dalam skala yang luas dapat dihindari.Ditinjau dari segi pertanian, 
areal pertanian di sekitar kawasan perkotaan memiliki resiko yang lebih rentan terhadap berbagai ancaman kerusakan khususnya bencana banjir. Diketahui bahwa terdapat areal pertanian seluas 3.488,40 ha dari total 43619,85 ha lahan sepanjang daerah aliran sungai Talllo (Surni., et al, 2015). Selain itu, analisa ini juga merupakan landasan pemikiran yang sangat penting dalam pembangunan jembatan dan bangunan hidrologi lainnya.

Salah satu cara memperhitungkan besarnya debit rencana pada suatu DAS adalah adalah dengan menggunakan model hidrologi. Model HEC-HMS (Hydrologic Engineering Center's - Hydrologic Modeling System) merupakan salah satu model hidrologi yang dimanfaatkan untuk analisis debit banjir dilokasi control point dari sistem peringatan dini banjir yang akan dibangun. Oleh karena itu, perhitungan dan permodelan besarnya debit banjir rencana perlu dilakukan untuk mengetahui besarnya debit banjir rencana yang akan terjadi selama periode waktu tertentu di DAS Tallo dengan menggunakan model HEC-HMS.

\section{Tujuan dan Kegunaan}

Tujuan dari penelitian ini adalah untuk mengetahui besarnya debit banjir rencana yang akan terjadi selama periode ulang 2, 5, 20 dan 50 tahunan di DAS Tallo.

Hasil yang didapatkan bisa digunakan untuk menentukan daerahdaerah yang mengalami banjir dan kemampuan sungai dalam menampung kelebihan debit air, serta menjadi salah satu dasar pemikiran dalam membuat perencanaan bangunan air seperti jembatan maupun bangunan pengendalian banjir.

\section{Luaran dan Batasan}

Luaran yang diharapkan dari penelitian ini adalah nilai debit banjir rencana, hydrograph aliran, dan video simulasi genangan banjir.

Dalam penelitian ini ada beberapa hal yang menjadi batasan untuk menghindari pembahasan yang lebih luas dari ruang lingkup bahasan penulisan, antara lain sebagai berikut:

1. Curah hujan $(\mathrm{CH})$ jam-jaman yang digunakan merupakan hasil perhitungan dari $\mathrm{CH}$ harian rencana yang dikonversi menggunakan metode Mononobe bukan hasil pengamatan langsung di lapangan.

2. Genangan banjir yang dimodelkan sepanjang DAS Tallo hanya merupakan hasil luapan debit sungai dengan tidak memperhitungan faktor-faktor lain penyebab genangan.

3. Pengaruh pasang surut air laut tidak diperhitungkan.

\section{TINJAUAN PUSTAKA}

\section{Daerah Aliran Sungai}

Pengertian daerah aliran sungai (DAS) adalah keseluruhan daerah kuasa (regime) sungai yang menjadi alur pengatus (drainage) utama.Pengertian DAS sepadan dengan istilah dalam bahasa inggris drainage basin, drainage area, atau river basin. Sehingga batas DAS merupakan garis bayangan sepanjang punggung pegunungan atau tebing/bukit yang memisahkan sistem aliran yang satu dari yang lainnya. Dari pengertian ini suatu DAS terdiri atas dua bagian utama daerah tadah (catchment area) yang membentuk daerah hulu dan daerah penyaluran air yang berada di bawah daerah tadah (Fuadi, 2008).

Pada dasarnya, analisis hidrologi untuk menentukan besarnya debit banjir rancangan dan debit dominan tersebut merupakan pemahaman kuantitatif terhadap proses yang terjadi pada DAS yang ditinjau. Dalam hal ini, yang diinginkan adalah nilai aliran debit maksimum atau debit dominan yang dapat ditelusuri berdasarkan pemahaman hubungan kuantitatif antar dengan besarnya aliran sungai tersebut (Elisa, 2016).

Umumnya keluaran sistem DAS berupa aliran sungai dinyatakan dalam bentuk hidrograf, yaitu grafik hubungan antara waktu dan debit aliran. Konsep ini 
secara skematis ditunjukkan pada gambar berikut:

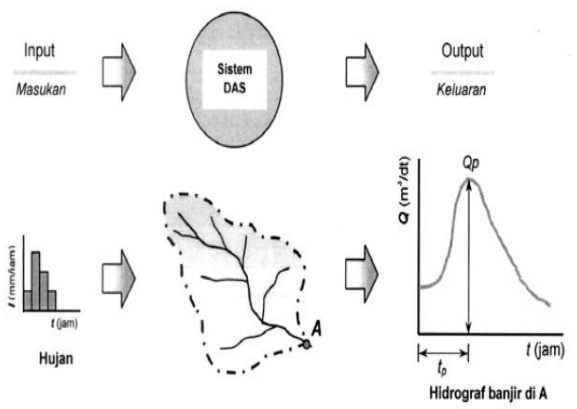

Gambar 2.1. Skema sistem daerah aliran sungai

Menurut Elisa (2016), terdapat beberapa parameter fisik DAS yang mempengaruhi karakteristik aliran yaitu sebagai berikut:

1. Bentuk DAS

2. Luas DAS

3. Topografi

4. Geologi

5. Kerapatan jaringan kuras

6. Tata guna lahan

\section{Daur Hidrologi}

Siklus hidrologi adalah suatu siklus atau sirkulasi air dari bumi ke atmosfer dan kembali lagi ke bumi yang berlangsung secara terus menerus (Anonim, 2016).

Siklus hidrologi secara umum dapat dilihat pada gambar berikut:



Gambar 2.3. Daur Hidrologi

Air yang masuk ke tanah melalui infiltrasi akan mengalami berbagai proses. Sebagian akan langsung diuapkan jika transfer dan dalam tanah ke permukaan memungkinkan. Oleh tanaman, air yang terinfiltrasi dapat pula ditransfer ke atmosfer melalui proses transpirasi. Sisa air infiltrasi akan mengisi kekurangan lengas tanah dan jika jumlahnya cukup besar akan dapat memberikan masukan ke tampungan air tanah dan sebagian dapat mengalir secara mendatar yang disebut dengan aliran antara (interfiow). Laju aliran pada tampungan air tanah akan menyebabkan terjadinya aliran dasar (base flow). Menurut Elisa (2016), aliran yang terukur di sungai terdiri dari unsur-unsur aliran berikut:

a) limpasan permukaan,

b) aliran antara (interfiow),

c) aliran dasar (base flow)

d) curah hujan yang jatuh pada sungai (channel rainfall).

\section{Permodelan Debit Banjir Rencana}

Banjir rancangan adalah besarnya debit banjir yang ditetapkan sebagai dasar penentuan kapasitas dan mendimensi bangunan-bangunan hidraulik (termasuk bangunan di sungai), sedemikian hingga kerusakan yang dapat ditimbulkan baik langsung maupun tidak langsung oleh banjir tidak boleh terjadi selama besaran banjir tidak terlampaui.

Dalam perhitungan banjir rencana tidak semua nilai dari suatu variabel hidrologi terletak atau sama dengan nilai rata-ratanya, tetapi kemungkinan ada nilai yang lebih besar atau kecil dari nilai rataratanya. Besarnya dispersi dilakukan dengan pengukuran dispersi, yakni melalui perhitungan parametrik statistik untuk $(\mathrm{Xi}-$ $\mathrm{X}),(\mathrm{Xi}-\mathrm{X})^{2},(\mathrm{Xi}-\mathrm{X})^{3},(\mathrm{Xi}-\mathrm{X})^{4}$ terlebih dahulu, dimana $\mathrm{Xi}=$ Besarnya curah hujan DAS (mm) dan $X=$ Rata-rata curah hujan maksimum daerah (Notonegoro, 2008).

Menurut Novitasari (2012), macam pengukuran dispersi antara lain sebagai berikut:

1. Standart Deviasi (S)

2. Koefisien Skewness (Cs)

3. Koefisien Kurtosis (Ck)

4. Koefisien Variasi (Cv)

Selain pengukuran dispersi, penggunaan jenis metode sebaran yang dipakai dalam penentuan curah hujan rencana sangat penting untuk dilakukan karena tidak semua jenis metode sebararan sesuai dengan kondisi wilayah 
penelitian.Ada empat jenis metode sebaran yang digunakan dalam perencanaan banjir yaitu Gumbel, Log-Pearson III, LogNormal, dan Normal.Tabel 2.2. menunjukkan beberapa parameter yang menjadi syarat penggunaan suatu metode sebaran. Dari tabel tersebut ditunjukkan beberapa nilai $\mathrm{Cs}, \mathrm{Cv}$, dan $\mathrm{Ck}$ yang menjadi persyaratan dari penggunaan empat jenis metode sebaran.

Tabel 2.2. Nilai parameter masing-masing jenis metode sebaran

\begin{tabular}{|l|l|l|l|l|}
\hline & GUMBEL & $\begin{array}{l}\text { LOG- } \\
\text { PEARSON } \\
\text { III }\end{array}$ & $\begin{array}{l}\text { LOG- } \\
\text { NORMAL }\end{array}$ & $\begin{array}{l}\text { NOR } \\
\text { MAL }\end{array}$ \\
\hline $\begin{array}{l}\text { PARA- } \\
\text { METE } \\
\text { R }\end{array}$ & $\mathrm{Cs} \approx 1.14$ & $\mathrm{Cs} \neq 0$ & $\mathrm{Cs} \approx 1.13$ & $\begin{array}{l}\mathrm{Cs} \approx \\
0\end{array}$ \\
\cline { 2 - 5 } & $\mathrm{Ck} \approx 5.40$ & $\mathrm{Cv} \approx 0.3$ & $\mathrm{Ck} \approx 5.38$ & $\begin{array}{l}\mathrm{Ck} \approx \\
3\end{array}$ \\
\hline
\end{tabular}

Sumber: Notonegoro, 2008.

Model adalah representasi atau gambaran dari suatu keadaan (states), obyek (objects), dan kejadian (events). Representasi tersebut harus diungkapkan dalam bentuk sederhana, yaitu dengan mengeliminasi atau meminimalkan variabel-variabel lain yang rumit dan tidak terkait secara langsung dengan model tersebut. Repesentasi tersebut dinyatakan dalam bentuk sederhana yang dapat dipergunakan untuk berbagai macam tujuan penelitian. Penyederhanan dilakukan secara representatif terhadap perilaku proses yang relevan dari keadaan yang sebenarnya. Hal yang sama dapat dinyatakan bahwa model hidrologi adalah sebuah sajian sederhana (simple representation) dari sebuah sistem hidrologi yang kompleks (Harsoyo, 2010).

Menurut Harsoyo (2010), terdapat beberapa model hidrologi skala DAS dan aplikasinya yang sering dipakai di Indonesia sesuai dengan karakteristik parameter dan fungsinya masing-masing, diantaranya sebagai berikut:
1. Model HEC-HMS (Hydrologic Engineering Center's Hydrologic Modeling System)

2. Model ANSWERS ( Areal Non-Point Source Watershed Environment Response Simulation)

3. Model TOPOG, yang dikembangkan oleh CSIRO (Commonwealth scientific and Industrial Research Organisation).

\section{HEC-HMS}

HEC-HMS adalah salah satu dari beberapa model hidrologi yangg dikembangkan olehUS Army Corps of Engineers - Institute for WaterResources. Model HEC-HMS merupakan programkomputer untuk menghitung pengalihragamanhujan dan proses routing pada suatu sistem DAS (Risyanto, 2011).

Data yang diperlukan antara lain meliputi hyterograph hujan dan peta topografi wilayah DAS. Hasil luaran program adalah perhitungan hidrograf aliran sungai pada lokasi yang dikehendaki dalam DAS.Konsep dasar perhitungan dari model HEC-HMS adalah data hujan sebagai input air untuk satu atau beberapa sub daerah tangkapan air (sub basin) yang sedang dianalisa. Model HEC-HMS dapat memberikan simulasi hidrologi dari puncak aliran harian untuk perhitungan debit banjir rencana dari suatu DAS (Kusumadewi, 2014).

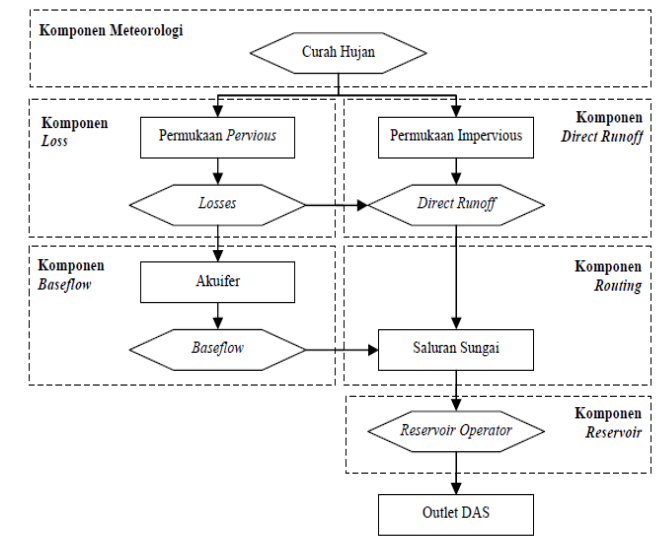

Gambar 2.5. Komponen Hujan-Limpasan dalam model HEC-HMS

Menurut Scharffenberg (2013), komponen utama dalam model HEC-HMS adalah sebagai berikut:

1. Basin model - berisi elemen-elemen DAS, hubungan antar elemen dan parameter aliran 
2. Meteorologic model - berisi data hujan dan penguapan

3. Control Specifications - berisi waktu mulai dan berakhirnya hitungan

4. Time series data - berisi masukan data antara lain hujan, debit

5. Paired data - berisi pasangan data seperti hidrograf satuan aliran/limpasan permukaan.

\section{Metode SCS-CN}

Metode SCS-CN didasarkan pada persamaan keseimbangan air dengan duahipotesis mendasar. Hipotesis pertama menyamakan secara langsung rasio jumlah permukaan limpasan(Q) dan total curah hujan (P) (atau maksimum potensial runoff permukaan)dengan rasio jumlah infiltrasi aktual (F) dan jumlah potensiretensi maksimum (S). Hipotesis kedua berhubungan dengan abstraksi awal $\left(\mathrm{I}_{\mathrm{A}}\right)$ kepotensial retensi maksimal. Dengan demikian, menurut Mishra (2013), metode SCS-CN terdiri dari:

1.Persamaan keseimbangan air:

$$
\mathrm{P}=\mathrm{I}_{\mathrm{A}}+\mathrm{F}+\mathrm{Q}
$$

2. Hipotesis proportional equality:

$$
\frac{Q}{P-\mathrm{Ia}}=\frac{F}{S}
$$

3. HipotesisI $\mathrm{A}_{\mathrm{A}} \mathrm{-s}$ :

$$
\mathrm{I}_{\mathrm{A}}=£ . \mathrm{S}
$$

di mana $\mathrm{P}=$ Total curah hujan, $\mathrm{I}_{\mathrm{A}}=$ awal abstraksi; $\mathrm{F}=$ infiltrasi kumulatif , $\mathrm{Q}=$ limpasan langsung, dan $S=$ potensi maksimal retensi atau infiltrasi, juga digambarkan sebagaipotensi awal abstraksi retensi. Semua jumlah dalampersamaan diatasdapat dilihat pada unit volumetrik berikut:

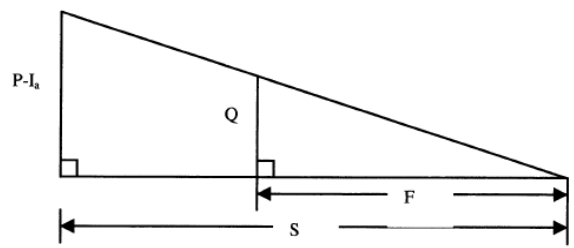

Gambar 2.6. Konsep proporsional Unit Hidrograf (UH)
Hidrograf satuan sintetik merupakan hidrograf satuan yang dihasilkan dari parameter-parameter fisik suatu DAS. Parameter hidrograf satuan sintetik yang dikemukakan adalah waktu tenggang (time lag, tl), waktu dasar (time base, $t b$ ), dan debit puncak (peak discharge, $Q p$ ). Kedalaman unit curah hujan berlebih dapat $1 \mathrm{~mm}, 1 \mathrm{em}$, atau 1 inci, dan durasi unit dapat 1-jam, 2-jam, 6jam, 12-jam, 24 jam, dan lain-lain sesuai durasi berlangsungnya hujan. Untuk daerah tangkapan menengah, satuan durasi umumnya dalam kisaran 1-6 jam (Mirsha, 2013).

Konsep hidrograf satuan melibatkan dua asumsi penting yaitu linearitasdan superposisi. Hidrograf untuk tinggi curah hujan-limpasan juga dapat diperoleh hanya dengan mengalikan koordinat hidrograf satuan dengantinggi curah hujan-limpasan. Ini mengikuti asumsi linearitas. Namun, hanya mungkin dengan asumsi bahwa basis waktu tetap konstanterlepas dari kedalaman curah hujan-limpasan.

\section{METODOLOGI PENELITIAN}

\section{Waktu dan Tempat}

Penelitian mengenai "Hydrograph Debit Banjir Rencana pada Daerah Aliran Sungai (DAS) Tallo Makassar dengan Model Hidrologi HEC-HMS" dilaksanakan pada bulan September 2016 hingga bulan November 2016, dengan wilayah kajian penelitian di Daerah Aliran Sungai Tallo dengan koordinat antara $5^{\circ} 6^{\prime}-5^{\circ} 16^{\prime}$ Lintang Selatan dan $119^{\circ} 3^{\prime}$ - $119^{\circ} 46^{\prime}$ Bujur Timur, Provinsi Sulawesi Selatan.

\section{Alat dan Bahan}

Alat yang digunakan dalam penelitian ini adalah komputer yang dilengkapi dengan software HEC-HMS 4.0, ArcGIS 10.1, dan Global Mapper.

Bahan yang digunakan yaitu data citra SRTM 30, data curah hujan dari 2 stasiun penakar hujan dan data tata guna lahan DAS Tallo. 


\section{Prosedur Kerja}

\section{Pengumpulan Data}

Penelitian ini didahului dengan pengumpulan bahan penelitian berupa data-data masukan yang terbagi atas dua jenis data yaitu data primer dan data sekunder.

\section{Data Primer}

Data primer merupakan data yang didapatkan melalui hasil verifikasi langsung di lapangan yaitu informasi mengenai tinggi muka air selama beberapa periode waktu pada beberapa titik pengamatan dari penduduk yang bermukim di sekitar bantaran sungai Tallo.

\section{Data Sekunder}

melalui

Data sekunder didapatkan dinas-dinas terkait seperti data curah hujan harian yang diperoleh dari Dinas Pekerjaan Umum Kota Makassar serta data citra SRTM 30 yang diunduh melalui USGS.

\section{Karakterisasi DAS Tallo}

Pembuatan peta jaringan sungai menggunakan beberapa softwere pendukung dan dilakukan melalui 3 tahap yaitu sebagai berikut:

1. Pemotongan data citra SRTM 30

Pemotongan data citra ini dilakukan dengan menggunakan Global Mapper yang bertujuan untuk memotong data citra sesuai dengan bentuk dan luas DAS Tallo.Pada tahap pemotongan, digunakan peta DAS Tallo dalam bentuk *shp sebagai template atau cetakan sehingga peta jaringan sungai DAS Tallo yang dihasilkan benar-benar sesuai dengan bentuk dan ukuran peta DAS Tallo yang resmi.

2. Deliniasi DAS

Citra yang telah dipotong pada Global Mapper kemudian
dideliniasi.Deliniasi DAS dilakukan di ArcGIS 10.1 > ArcMap melalui tahapan-tahapan deliniasi DAS pada umumnya agar jaringan sungai dan batasan DAS dapat ditampakkan dengan jelas.

3. Parameter fisik DAS Tallo

Setelah peta DAS Tallo dipotong dan dideliniasi, maka dilakukan karakterisasi parameter DAS Tallo dengan mengacu pada bentuk DAS, pola sungai, luas DAS dan tata guna lahan.

\section{Penentuan Curah Hujan Rencana}

Penentuan nilai curah hujan rencana dilakukan dengan beberapa tahap perhitungan sebagai berikut:

1. Menganalisis luas pengaruh stasiun hujan dengan metode Isohyet menggunakan softwere ArcGIS.

2. Menghitung curah hujan harian maksimum harian rata-rata DAS

3. Melakukan pengukuran dispersi dengan menggunakan beberapa persamaan parameter statistik (Novitasari, 2012).

$$
\begin{aligned}
& \bar{x}=\frac{1}{n} \sum_{i=1}^{n} X_{i} \\
& S=\frac{\sum_{i=1}^{n}\left(\mathrm{X}_{\mathrm{i}}-\bar{x}\right)^{2}}{(n-1)} \\
& C_{v}=\frac{\mathrm{S}}{\bar{x}} \\
& C_{S}=\frac{\Sigma\left(\mathrm{X}_{\mathrm{i}}-\bar{x}\right)^{3}}{(\mathrm{n}-1)(n-2) S^{3}} \\
& C_{k}=\frac{\frac{1}{n} \sum\left(\mathrm{X}_{\mathrm{i}}-\bar{x}\right)^{4}}{S^{4}}
\end{aligned}
$$

\section{keterangan:}

$\mathrm{S} \quad=$ Standar Deviasi

$\mathrm{C}_{\mathrm{V}}=$ Koefisien Variasi

$\mathrm{C}_{S}=$ Koefisien Skewness

$\mathrm{C}_{\mathrm{K}}=$ Koefisien kuartosis

$\mathrm{X}=$ Rata-rata curah hujan maksimum daerah

$\mathrm{Xi}=$ Besarnya curah hujan DAS (mm) 
$\mathrm{n}=$ nilai koefisien

4. Melakukan perhitungan distribusi hujan dengan metode sebaran normal dan metode sebaran Log Pearson III untuk menentukan jenis sebaran yang cocok.

5. Melakukan analisa frekuensi sesuai dengan ketentuan dan menguji kecocokan sebaran.

6. Melakukan perhitungan curah hujan rencana dengan metode sebaran yang sesuai dengan periode ulang 25 tahun.

7. Melakukan konversi curah hujan rencana ke curah hujan jam-jaman untuk disimulasikan pada HECHMS.

\section{Simulasi HEC-HMS}

Peta jaringan sungai DAS Tallo dan nilai curah hujan rencana yang telah dikonversi ke curah hujan jam-jaman selanjutnya akan dimodelkan dengan menggunakan program HEC-HMS. Pemodelan debit banjir rencana ini dilakukan dengan tahapan sebagai berikut:

1. Membuka softwere HEC-HMS 4.0

2. Membuat suatu project baru (new project)

3. Menyusun HMS Component Models
a) Basin Model
b) Meteorologic Model
c) Control Specification

4. Menyusun Time Series Data, seperti:
a) Data hujan

b) Data debit

5. Menyusun Paired data, seperti:

a) Hidrograf satuan

b) Hubungan Elevasi-tampungan

6. Memilih dan mengisi Basin Models

7. Mengisi formMeteorologic Model

8. Mengisi formControl Specification

9. Mengisi formTime-series Data

10. Mengisi formPaired Data

11. Memeriksa Data

12. Melakukan Simulation

13. Menyajikan hasil simulasi dalam bentuk hydrograph dan nilai output.

\section{Pembuatan Simulasi Genangan Banjir di ArcScene}

Untuk melihat pola genangan banjir yang dimodelkan di HEC-HMS, maka dilakukan simulasi genangan banjir pada softwere ArcGIS 10.1 dengan tahapan sebagai berikut:

1. Membuka softwere ArcGIS $10.1>$ ArcScene

2. Memasukkan data DEM, data *shp laut dan peta jaringan sungai DAS Tallo serta peta DAS Tallo yang diunduh di google earth.

3. Mengubah data input yang masih dalam bentuk 2 dimensi kedalam bentuk 3 dimensi menggunakan fungsi base height pada properties

4. Mengonversi nilai elevasi setiap layer ke dalam scene units

5. Mengaktifkan pilihan Animation pada extension ArcScene

6. Mengatur ketinggian debit banjir rencana pada animation manager sesuai dengan hasil permodelan di HEC-HMS

7. Mengamati hasil simulasi dengan memilih play pada animation controls

8. Mengonversi hasil simulasi menjadi video simulasi menggunakan pilihan export animation

\section{Penentuan Nilai Debit Banjir Rencana secara Hipotetik}

Untuk melakukan perbandingan dengan nilai debit banjir rencana yang dimodelkan dalam program HEC-HMS, maka dilakukan penentuan nilai debit banjir rencana secara hipotetik. Tahapan untuk menentukan nilai hipotetik debit banjir rencana DAS Tallo adalah sebagai berikut:

1. Melakukan ground truth DAS Tallo setelah dilakukan simulasi (tanggal 17 April 2017) untuk mendapatkan informasi dari penduduk yang bermukim di daerah hilir sungaimengenai data debit maksimum (kejadian banjir).

2. Mengambil titik koordinat pada lokasi yang disurvei sesuai dengan informasi yang dikemukakan oleh warga 
mengenai batas genangan banjir maksimum dalam kurun waktu tertentu.

3. Membandingkan nilai hipotetik genangan banjir di lapangan

berdasarkan hasil survey dan nilai debit maksimum hasil permodelan/simulasi

\section{Bagan Alir Penelitian}

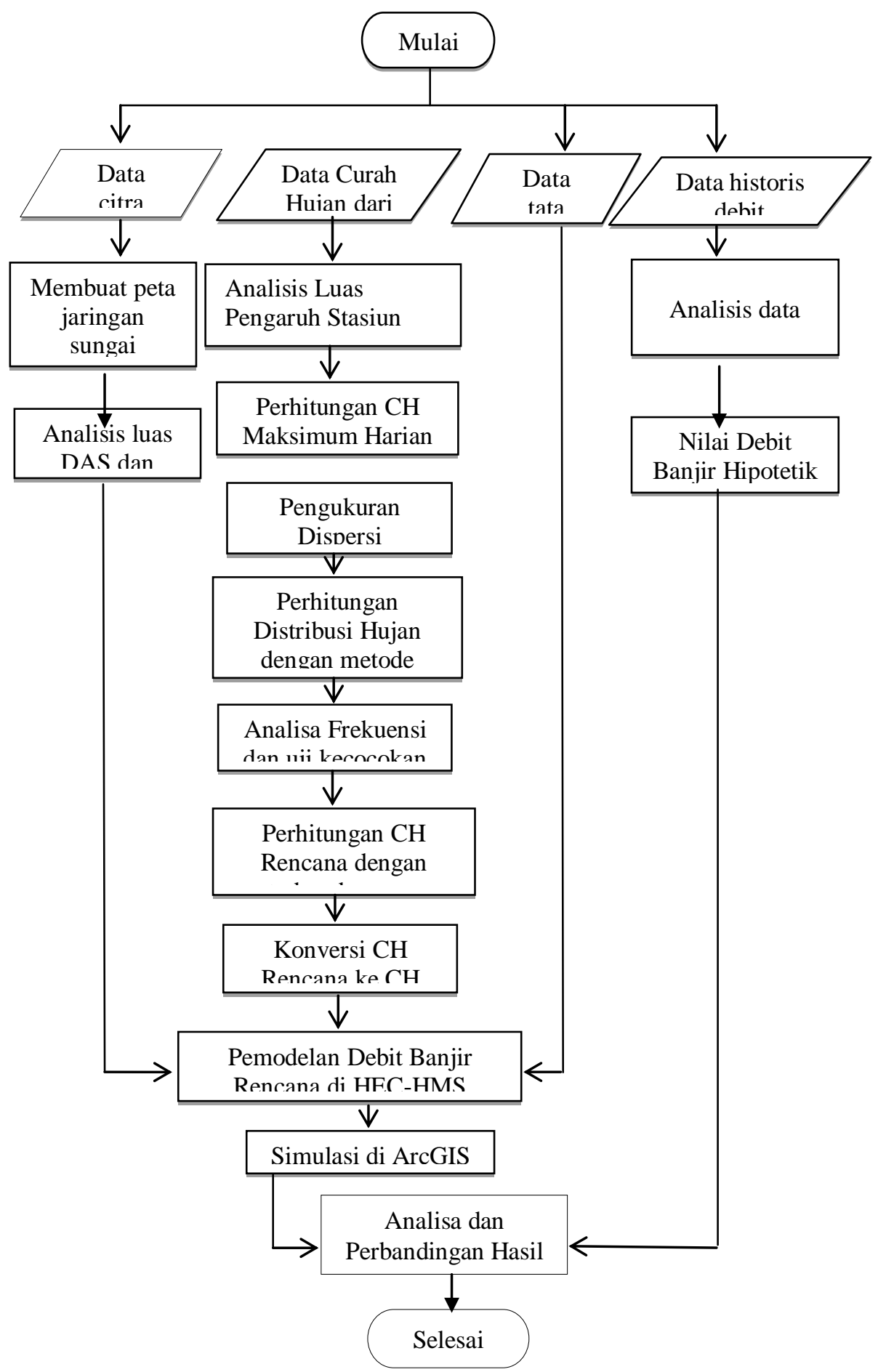




\section{HASIL DAN PEMBAHASAN}

\section{Deskrispsi dan Karakteristik DAS Tallo}

Daerah Pengaliran Sungai Tallo terletak di 3 (tiga) wilayah administrasi kota dan kabupaten yaitu Kota Makassar (meliputi Kecamatan Tamalate, Panakkukang, Biringkanaya, Bontoala, Tallo, Tamalanrea, Manggala, dan Rappocini), Kabupaten Gowa (meliputi Kecamatan Bontomarannu, Sombaopu, Parangloe, dan Tinggimoncong) serta Kabupaten Maros (meliputi Kecamatan Mandai, dan Tanralili) dengan luas areal keseluruhan sebesar $\pm 436 \mathrm{~km}^{2}$. Berikut adalah peta jaringan sungai dari DAS Tallo:

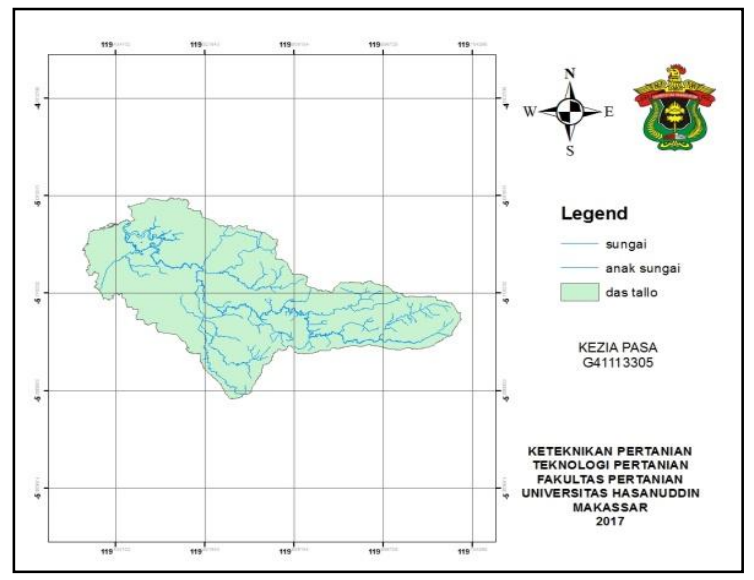

Gambar 4.1. Peta Jaringan Sungai DAS Tallo

Lebar minimum sungai Tallo adalah $35 \mathrm{~m}$ dan maksimum $60 \mathrm{~m}$. Sedangkan untuk lebar rata-rata diperoleh $48 \mathrm{~m}$. Pada musim hujan, debit sungai bisa mencapai debit maksimum yaitu $79,68 \mathrm{~m}^{3} / \mathrm{s}$. Ketinggian muka air mencapai 3,18 m dari dasar sungai. Pada musim kemarau, debit sungai menjadi debit minimum yaitu 21,14 $\mathrm{m}^{3} / \mathrm{s}$. Ketinggian muka air hanya $1,66 \mathrm{~m}$ dari dasar sungai. Ketinggian titik Bench Mark yang terpasang adalah 1,97 $\mathrm{m}$ dari MSL (Sutrisno, 2015). Nilai elevasi dasar sungai dari hulu sampai hilir dapat dilihat pada gambar 4.2.

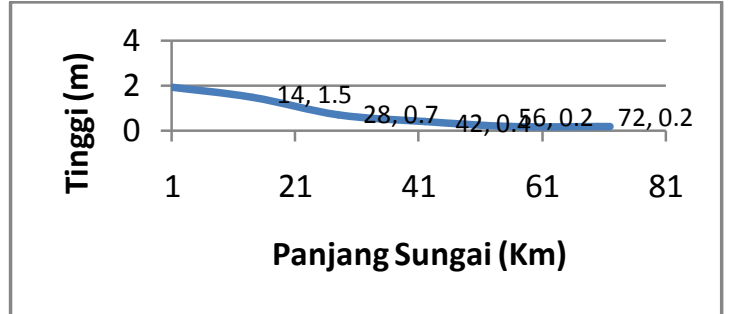

Gambar 4.2. Grafik ketinggian titik elevasi sungai

Kemiringan atau elevasi dasar sungai pada model grafik tersebut memperlihatkan bahwa kelandaian sungai disetiap 14 kilometer dari hulu sampai hilir memiliki nilai yang berbeda-beda. Nilai kemiringan maksimum terletak pada kilometer 14-28 dengan nilai elevasi $0.8 \mathrm{~m}$ dari MSL sementara nilai minimum terletak pada kilometer 42-72 dengan nilai $0.2 \mathrm{~m}$.

Berikut ini adalah analisis terakhir data tata guna lahan DAS Tallo:

Tabel 4.1. Tata guna lahan DAS Tallo

\begin{tabular}{|c|c|c|}
\hline $\begin{array}{l}\text { Penggunaa } \\
\text { n Lahan }\end{array}$ & $\begin{array}{l}\text { Luas } \\
\text { (Ha) }\end{array}$ & $\begin{array}{l}\text { Persentase } \\
(\%)\end{array}$ \\
\hline Hutan & 8480,55 & 19,44 \\
\hline Kebun & 18045,73 & 41,37 \\
\hline Padang & 2285,68 & 5,24 \\
\hline Perairan Darat & 1514,99 & 3,47 \\
\hline Perkebunan & 161,53 & 0,37 \\
\hline Permukiman & 7233,41 & 16,58 \\
\hline Persawahan & 3488,40 & 8,00 \\
\hline $\begin{array}{l}\text { Pertanian tanah } \\
\text { kering } \\
\text { semusim }\end{array}$ & 917,19 & 2,10 \\
\hline Lahan Terbuka & 1492,38 & 3,42 \\
\hline Total & 43619,85 & 100,00 \\
\hline
\end{tabular}

Sumber: Analisis Geospasial Balai Lahan dan Kehutanan Indonesia tahun 2009.

\section{Permodelan Banjir Rencana HEC-HMS}

Elemen-elemen yang digunakan untuk mensimulasikan limpasan pada penelitian ini adalah subbasin, dan junction. Subbasin merupakan elemen model daerah tangkapan air DAS Tallo sementara junction menjadi penghubung antar 
subbasin yang dapat dilihat pada gambar dibawah ini:

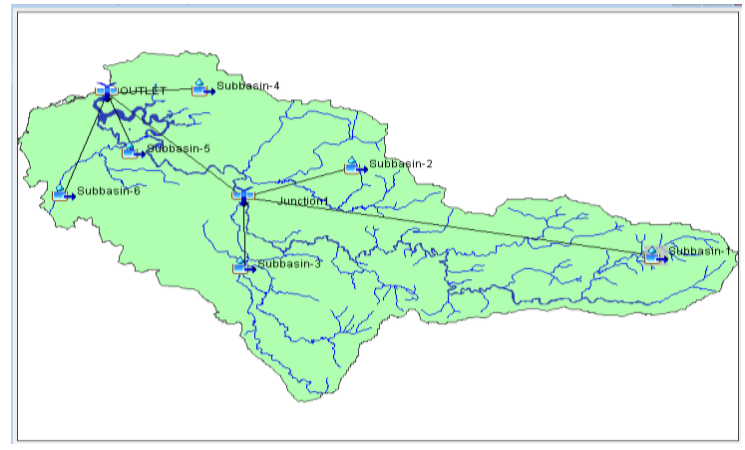

Gambar 4.3. Model Subbasin DAS Tallo

\section{Masukan dan Parameter}

Dalam memodelkan banjir rencana dalam HEC-HMS, ada beberapa input dan parameter yang menjadi dasar permodelan.

Karena keterbatasan data lapangan yang dibutuhkan didalam penggunaan metode-metode perhitungan tersebut, maka penulis memilih metode SCS curve number $(C N)$ yang dianggap paling mudah di aplikasikan dalam perhitungan dan nilainya dapat berupa asumsi sementara.

\section{A. Input CH Jam-jaman}

Dalam penelitian ini digunakan dua stasiun hujan yaitu Stasiun Hujan Panakkukang dan stasiun hujan Senre.Luas pengaruh stasiun hujan panakkukang yang didapatkan melalui hasil perhitungan polygon thiessen adalah 15127,39 ha atau $151,27 \mathrm{~km}^{2}$ sementara untuk stasiun hujan senre luas areanya adalah 28573,87 ha atau $285,74 \mathrm{~km}^{2}$.

Berikut adalah nilai $\mathrm{CH}$ jamjaman selama beberapa periode waktu yang menjadi nilai input permodelan banjir rencana DAS Tallo:

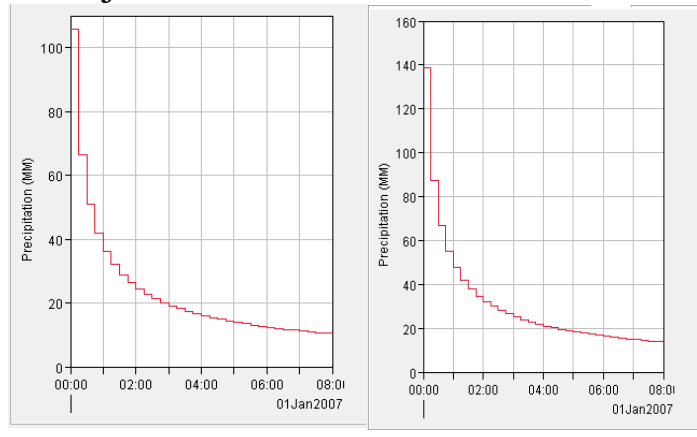

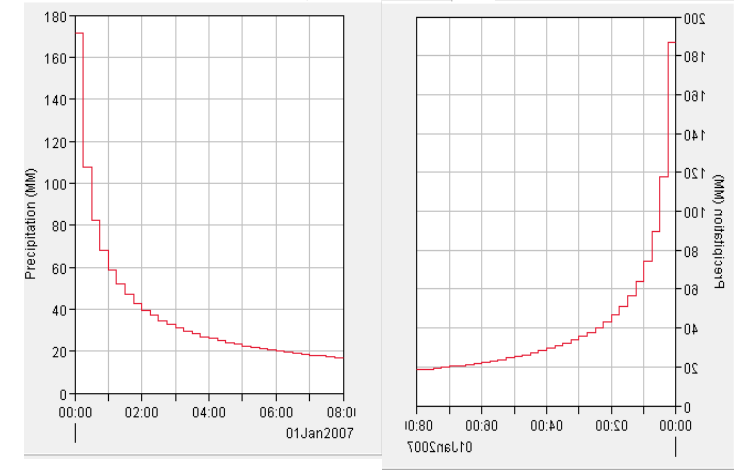

Gambar 4.5. Grafik CH Jam-jaman untuk Periode Waktu 2, 5, 20 dan 50 tahunan

Interval waktu yang digunakan untuk setiap model $\mathrm{CH}$ jam-jaman diatas adalah 15 menit. Meskipun nilai curah hujan (precipitation) puncak memiliki perbedaan yang cukup signifikan namun pola penurunan intensitas hujan selama 8 jam hampir sama disetiap periode waktu.

\section{B. Parameter Permodelan}

Dalam memodelkan debit banjir rencana DAS Tallo di HEC-HMS digunakan model perhitungan SCS CN (Soil Conservation Service Curve number).

Ada 3 parameter penting yang menjadi dasar permodelan metode SCS yaitu loss rate method, SCS Transform dan baseflow.

\section{Proses Kehilangan Air}

Nilai Curve number dan impervious disetiap subbasin mengasumsikan tingkat permeabilitas atau persentase resapan air tanah berdasarkan nilai tata guna lahan. Berikut adalah tabel nilai curve number dan impervious tanah di setiap subbasin:

Tabel 4.2. Nilai curve number dan impervious tanah

\begin{tabular}{|l|l|l|}
\hline Subbasin & $\begin{array}{l}\text { Curve } \\
\text { number }\end{array}$ & $\begin{array}{l}\text { Impervious } \\
(\%)\end{array}$ \\
\hline $\begin{array}{l}\text { Subbasin } \\
\text { Jenepatunga }\end{array}$ & 20,91 & 0,91 \\
\hline $\begin{array}{l}\text { Subbasin } \\
\text { Jenelemoa }\end{array}$ & 40,00 & 5,00 \\
\hline
\end{tabular}




\begin{tabular}{|l|l|l|}
$\begin{array}{l}\text { Subbasin } \\
\text { Lempangang }\end{array}$ & 40,03 & 4,00 \\
\hline $\begin{array}{l}\text { Subbasin } \\
\text { Tiocekang }\end{array}$ & 20,00 & 1,90 \\
\hline $\begin{array}{l}\text { Subbasin } \\
\text { Bangkala }\end{array}$ & 25,00 & 3,00 \\
\hline $\begin{array}{l}\text { Subbasin } \\
\text { Rappokalling }\end{array}$ & 70,00 & 14,00 \\
\hline
\end{tabular}

\section{Transformasi hidrograf satuan limpasan}

Dalam penelitian ini, nilai SCS Transform disetiap subbasin dapat diasumsikan sama rata dengan graph time standard:

Tabel 4.3. Nilai lag time setiap subbasin

\begin{tabular}{|l|l|l|}
\hline Subbasin & $\begin{array}{l}\text { Graph } \\
\text { Time }\end{array}$ & $\begin{array}{l}\text { Lag Time } \\
\text { (MIN) }\end{array}$ \\
\hline $\begin{array}{l}\text { Subbasin } \\
\text { Jenepatunga }\end{array}$ & Standard & 78 \\
\hline $\begin{array}{l}\text { Subbasin } \\
\text { Jenelemoa }\end{array}$ & Standard & 83 \\
\hline $\begin{array}{l}\text { Subbasin } \\
\text { Lempangang }\end{array}$ & Standard & 108 \\
\hline $\begin{array}{l}\text { Subbasin } \\
\text { Tiocekang }\end{array}$ & Standard & 138 \\
\hline $\begin{array}{l}\text { Subbasin } \\
\text { Bangkala }\end{array}$ & Standard & 150 \\
\hline $\begin{array}{l}\text { Subbasin } \\
\text { Rappokalling }\end{array}$ & Standard & 150 \\
\hline
\end{tabular}

\section{Aliran Dasar}

Aliran dasar (baseflow) terjadi akibat limpasan yang berasal dari kejadian presipitasi terdahulu yang tersimpan secara temporer dalam DAS Tallo, ditambah dengan limpasan subpermukaan yang tertunda dari suatu kejadian hujan. Dalam perhitungannya, penulis menggunakan metode konstan bulanan didalam penentuan besaran baseflow. Nilai konstan bulanan yang diasumsikan adalah sebagai berikut:

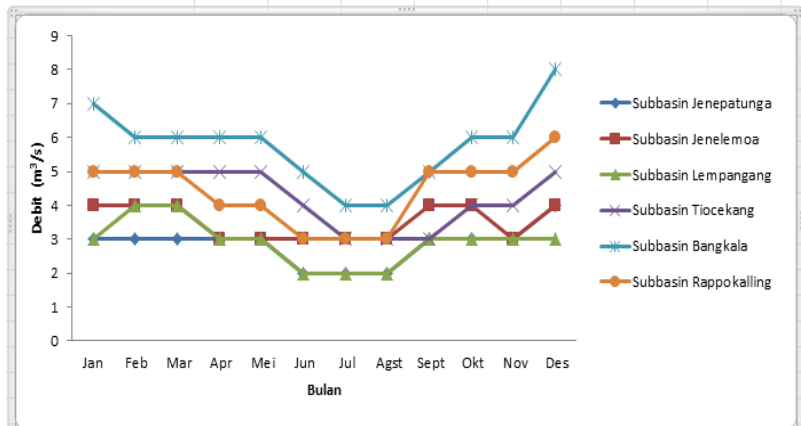

Gambar 4.6. Grafik nilai baseflow setiap subbasin

\section{Luaran Permodelan HMS}

Nilai debit banjir rencana DAS Tallo untuk setiap periode waktu, yaitu 2 tahunan, 5 tahunan, 20 tahunan dan 50 tahunan didapatkan setelah proses running data masukan selesai. Rincian nilai debit banjir rencana dan volume banjir untuk setiap periode waktu adalah sebagai berikut:

\section{Periode Banjir Rencana 2 Tahunan}

Hasil permodelan untuk periode ulang 2 tahunan dapat dilihat pada gambar 4.7.

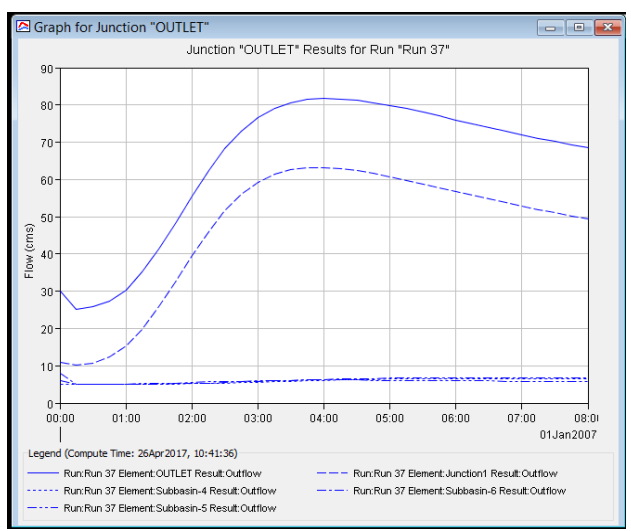

Gambar 4.7.Hydrograph aliran untuk periode 2 tahunan

Nilai debit puncak (peak discharge) yang diperoleh untuk periode ulang 2 tahunan berdasarkan hydrograph tersebut adalah sebesar $81,80 \mathrm{~m}^{3} / \mathrm{s}$ daerah hilir atau outlet sungai. Dari nilai tersebut dapat dilihat bahwa nilai debit banjir rencana yang disimulasikan untuk periode ulang 2 tahunan hanya memiliki kenaikan sekitar $\pm 2 \mathrm{~m}^{3} / \mathrm{s}$ dari kapasitas tampung maksimum sungai Tallo yang pada 
musim hujan debit maksimumnya dapat mencapai $79,68 \mathrm{~m}^{3} / \mathrm{s}$, artinya kejadian banjir untuk skala pengulangan 2 tahunan sangat kecil kemungkinan. Time peak untuk periode ini adalah 4 jam.

\section{Periode Banjir Rencana 5 Tahunan}

Gambar 4.8. menampilkan nilai debit puncak untuk periode ulang 5 tahunan.

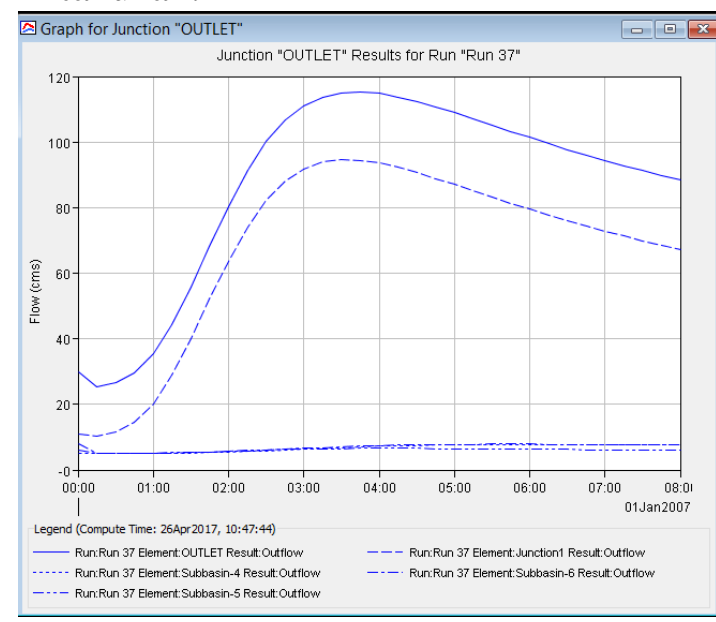

Gambar 4.8.Hydrograph aliran untuk periode 5 tahunan

Debit banjir rencana untuk periode ulang 5 tahunan pada outlet diperoleh sebesar $115,30 \mathrm{~m}^{3} / \mathrm{s}$. Dari nilai tersebut dapat dilihat bahwa terjadi peningkatan nilai debit rencana dibandingkan untuk periode ulang 2 tahunan sebelumnya. Jika debit maksimum adalah $79,69 \mathrm{~m}^{3} / \mathrm{s}$ maka dapat terjadi peningkatan hingga $35,61 \mathrm{~m}^{3} / \mathrm{s}$ untuk setiap 5 tahun. Hal ini mengakibatkan potensi kejadian banjir menjadi meningkat akibat volume tampungan yang lebih kecil dari debit air yang mengalir.

\section{Periode Banjir Rencana 20 Tahunan}

Periode banjir rencana 20 tahunan memberikan nilai debit puncak yang dapat dilihat pada gambar hydrograph berikut:

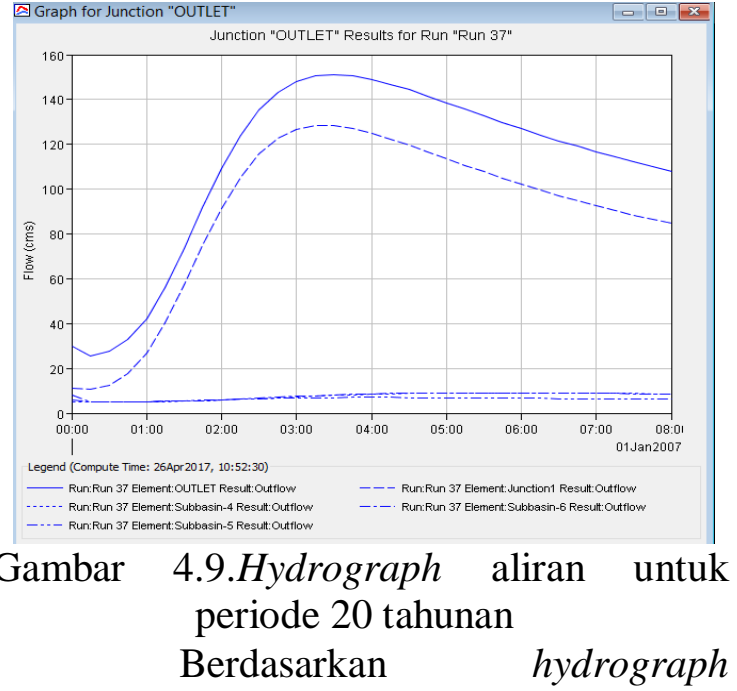

periode ulang 20 tahunan tersebut, terlihat nilai debit banjir rencana mencapai 151,20 $\mathrm{m}^{3} / \mathrm{s}$. Jika debit maksimum adalah 79,69 $\mathrm{m}^{3} / \mathrm{s}$ maka terjadi kenaikan debit senilai $71,51 \mathrm{~m}^{3} / \mathrm{s}$ untuk setiap 20 tahun.Hal ini mengakibatkan potensi kejadian banjir menjadi meningkat akibat volume tampungan yang lebih kecil dari debit air yang mengalir. Waktu untuk mencapai debit puncak (time peak) lebih cepat dibandingkan dua periode ulang sebelumnya yaitu antara jam ke 3 dan 4 .

\section{Periode Banjir Rencana 50 Tahunan}

Nilai debit puncak untuk periode ulang 50 tahunan dapat dilihat pada gambar 4.10.

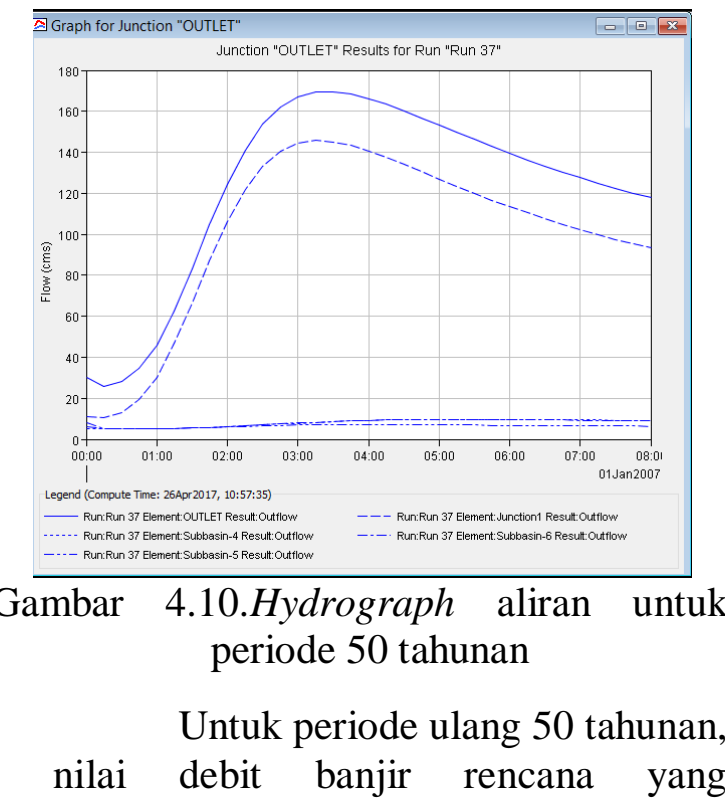


didapatkan adalah 169,50 m³ $/ \mathrm{s}$. Artinya, jika debit maksimum adalah $79,70 \mathrm{~m}^{3} / \mathrm{s}$ maka terjadi peningkatan $\mathrm{Q}_{\text {maks }}$ hingga $89,80 \mathrm{~m}^{3} / \mathrm{s}$ atau lebih dari 2 kali lipat dari debit maksimum yang normal. Nilai volume tinggi air di daerah hilir juga mengalami peningkatan yang cukup signifikan hingga $3588 \mathrm{~m}^{3}$. Dari nilai tersebut dapat disimpulkan bahwa potensi kejadian banjir untuk setiap periode pengulangan 50 tahun cukup besar.Time peak untuk periode ini tetap sama dengan periode ulang 20 tahunan yaitu antara jam ke 3 dan 4 .

\section{Simulasi Genangan}

Simulasi genangan dimaksudkan untuk memperlihatkan naiknya genangan air sungai di titik-titik rawan banjir selama periode waktu tertentu sesuai dengan hasil yang didapatkan dari permodelan banjir rencana di HEC-HMS.Hasil permodelan HEC-HMS menampilkan volume air yang paling tinggi terletak pada subbasin 5 (Subbasin Bangkala) yang merupakan daerah hilir sungai.Untuk mengamati pola genangan banjir di area tersebut, maka dilakukan simulasi banjir di ArcScene, salah satu fasilitas ArcGIS 10.1 yang berbasis DEM.

Berikut adalah hasil simulasi dan verifikasi lapangan untuk setiap periode waktu:

\section{Periode waktu 2 tahunan}

Potensi kejadian banjir dan luas daerah genangan untuk periode waktu 2 tahunan dapat dilihat pada gambar berikut ini:

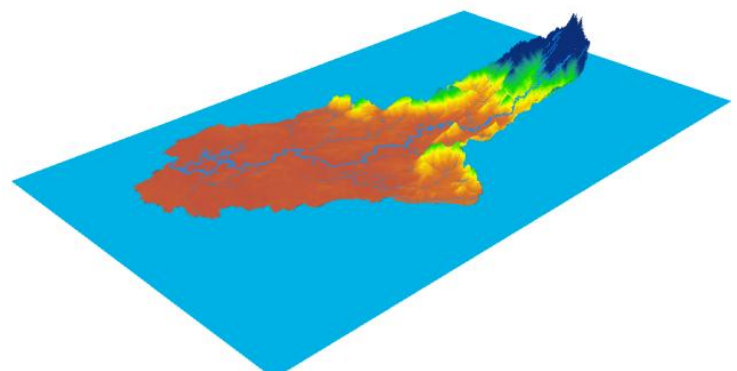

Gambar 4.12. Model genangan periode waktu 2 tahunan
Pada periode waktu 2 tahunan, genangan banjir tidak terlihat pada saat disimulasikan. Hal ini sesuai dengan hasil permodelan yang didapatkan sebelumnya di HEC-HMS, dimana debit banjir rencana yang didapatkan lebih kecil dibandingkan nilai debit maksimum yang dapat ditampung sungai pada saat musim hujan. Artinya kejadian banjir untuk skala pengulangan 2 tahunan akibat luapan sungai memiliki potensi yang sangat kecil atau tidak pernah terjadi.Hal ini membuat tampilan DEM yang disimulasikan tidak berbeda dari model awal sebelum dilakukan simulasi.

\section{Periode waktu 5 tahunan}

Gambaran daerah genangan banjir untuk periode ulang 5 tahunan dapat dilihat pada gambar berikut:

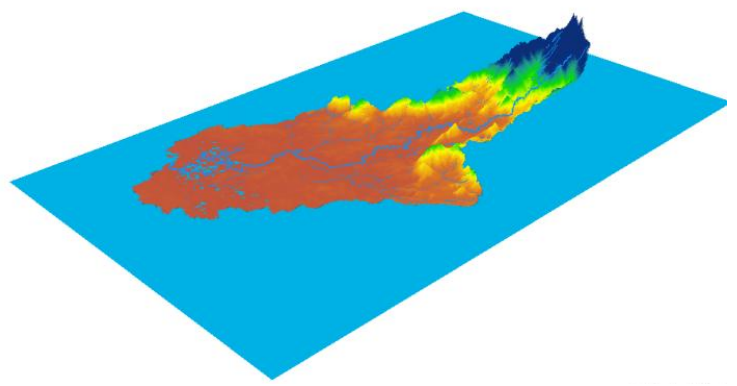

Gambar 4.13. Model genangan periode waktu 5 tahunan

Berbeda dengan hasil simulasi genangan banjir periode 2 tahunan, pada periode ulang 5 tahunan mulai terlihat genangan-genangan air akibat luapan sungai. Setelah didapatkan titiktitik daerah genangan banjir, maka dilakukan ground truth di titik-titik tersebut. Gambaran daerah atau titiktitik genangan banjir hasil simulasi dan verifikasi setelah ditinjau dengan peta wilayah dari Google Earth adalah sebagai berikut: 




Gambar 4.14.Lokasi Verifikasi Data 1

\section{Periode waktu 20 tahunan}

Genangan banjir yang terjadi untuk periode ulang 20 tahunan dapat dilihat pada gambar berikut ini:

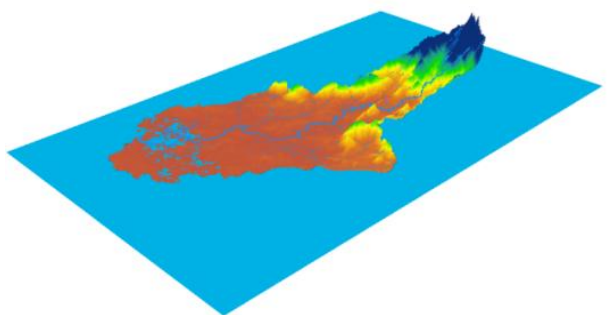

Gambar 4.15. Model genangan periode waktu 20 tahunan

Hasil simulasi tersebut memperlihatkan luas genangan banjir yang semakin besar dan melebar di beberapa titik dibandingkan dengan periode ulang 5 tahunan.Hal ini karena periode waktu yang lebih panjang.

Gambaran daerah atau titik-titik genangan banjir hasil simulasi dan verifikasi setelah ditinjau dengan peta wilayah dari Google Earth adalah sebagai berikut:

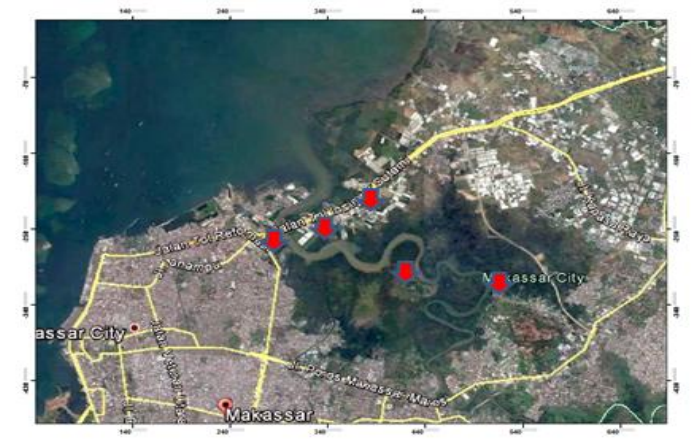

Gambar 4.16. Lokasi Verifikasi Data 2

\section{Periode waktu 50 tahunan}

Hasil simulasi untuk genangan banjir periode ulang 50 tahunan dapat dilihat pada gambar berikut:

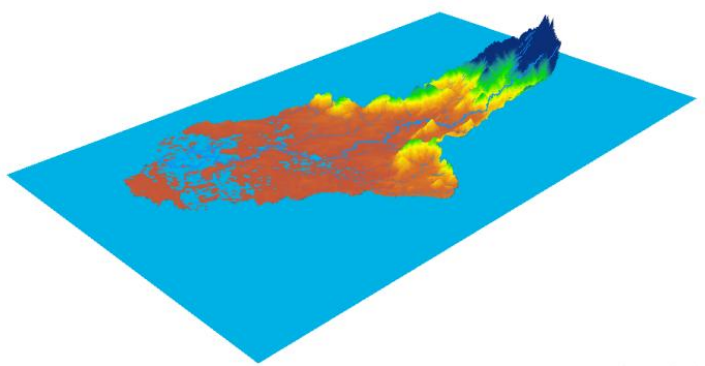

Gambar 4.17. Model genangan periode waktu 50 tahunan

Potensi genagan banjir akibat luapan sungai untuk periode ulang 50 tahunan sangat besar karena rentang waktu yang cukup panjang. Wilayah genangan cukup luas bahkan diluar kota Makassar. Tidak ada data yang cukup untuk memverifikasi hasil simulasi 50 tahunan ini, namun didalamnya sudah mencakup potensi kejadian banjir untuk 5 tahunan dan 20 tahunan.Berdasarkan hasil simulasi di DEM dan 2 periode waktu sebelumnya, maka titik-titik wilayah genangan banjir tersebut dapat dilihat pada Gambar 4.18.

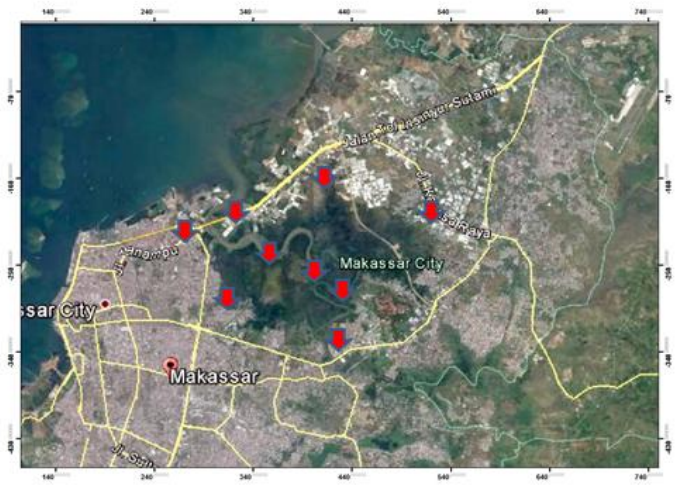

Gambar 4.18. Lokasi Verifikasi Data 3

\section{KESIMPULAN DAN SARAN}

\section{Kesimpulan}

Hasil penelitian permodelan debit banjir rencana DAS Tallo dapat disimpulkan sebagai berikut:

1. Nilai debit banjir dari HEC-HMS yang kemudian disimulasikan di ArcScene memberikan nilai lebar limpasan yang sesuai dengan hasil ground truth di lapangan. 
2. Nilai debit banjir untuk setiap periode waktu pada DAS Tallo dapat dimodelkan dengan baik di HEC-HMS.

3. Daerah-daerahadministratif yang memiliki potensi terjadinya banjir akibat luapan sungai adalah daerah Lakkang, Kera-Kera, Kampung Nelayan di daerah Hilir Sungai, Jl. Perintis Kemerdekaan.

\section{Saran}

Sebaiknya pengambilan data verifikasi di lapangan dilakukan di lebih banyak lagi titik atau wilayah sehingga pertimbangan mengenai akurasi permodelan dapat lebih baik.

\section{DAFTAR PUSTAKA}

Elisa. 2016. Fenomena Aliran Sungai.

Universitas Gadjah Mada:

Yogyakarta.

Fuadi, Zahrul. 2008. Tinjauan Daerah Aliran Sungai Sebagai Sistem Ekologi Dan Manajemen Daerah Aliran Sungai. Lentera: Vol 6, No.1.

Harsoyo, Budi. 2010. Review Modeling Hidrologi DAS di Indonesia. Jurnal Sains \& Teknologi Modifikasi Cuaca, Vol.11, No.1, 2010:41-47.

Kusumadewi, Hana Siti. 2014. Petunjuk

Penggunaan Model HEC-HMS

3.5.www.academia.edu

Notonegoro, Agung., Heri Pramawan.

2008. Perencanaan Teknis Embung

Silandak Sebagai Pengendali Banjir

Kali Silandak - Bab IV: Analisis

Hidrologi. Universitas Diponegoro:

Semarang.

Novitasari. 2012. Rekayasa Hidrologi I:

Perencanaan Banjir Rancangan.

https://novitasari.files.wordpress.co $\mathrm{m} / \mathrm{pdf}$.

Mishra, Surendra Kumar., Vijay P. Singh. 2013. Soil Conservation Service Curve Number (SCS-CN)

Methodology. Water Science and Technology Library:U.S.A.
Risyanto.2011. Aplikasi HEC-HMS Untuk Perkiraan Hidrograf Aliran Di DAS Ciliwung.Institut Pertanian Bogor : Bogor.

Scharffenberg, William A. 2013.

Hydrologic Modeling System (HECHMS) User's Manual. US Army Corps of Engineers. Washington DC.

Surni., Sumbangan Baja., Usman Arsyad. 2015. Dinamika Perubahan Penggunaan Lahan Terhadap Hilangnya Biodiversitas di Das Tallo, Sulawesi Selatan. PROS SEMNAS MASY BIODIV INDON Vol. 1 No.5 Hal.1050-1055, Agustus 2015.

Sutrisno. 2015. Kajian Potensi Sungai Tallo Sebagai Navigasi Sungai. Universitas Hasanuddin: Makassar. 